\title{
Isolation, Purification, and Physical and Chemical Properties of Neuraminidase Inhibitor No. $289^{\dagger}$
}

\author{
Wenlii LIN, Kunio OISHI and Ko AIDA \\ Institute of Applied Microbiology, The University of Tokyo, Japan \\ Received July 4, 1974
}

\begin{abstract}
The neuraminidase inhibitor produced by Streptomyces sp. No. 289 has been isolated from a culture filtrate and purified, and the properties of the purified preparation have been investigated. The inhibitor has a molecular weight of about 100,000 , being free from neuraminic acid or its analogs and consisting of $88 \%$ of sugar and $12 \%$ of protein. The sugar constituent is mainly composed of equal amounts of glucose and mannose, and the protein constituent lacks S-containing amino acids. An elementary analysis gives $37.33 \% \mathrm{C}, 6.12 \% \mathrm{H}$ and $1.29 \% \mathrm{~N}$. The activity of the inhibitor is stable to heating at $100^{\circ} \mathrm{C}$ for $10 \mathrm{~min}$ and to the actions of various proteolytic enzymes, but is weakened by periodate oxidation. These properties have proved that the inhibitor is completely different from those so far reported.
\end{abstract}

It had been believed that neuraminidase existed in pathogenic microorganisms as a non-metabolic enzyme which was related to the infection of the microorganisms to their hosts ${ }^{11}$ until the discovery that it was, in addition to pathogenic microorganisms, also widely distributed in non-pathogenic microorganisms and animals. ${ }^{2,3)}$ Since then, the in vivo functions of the enzyme as well as the effects of activators and inhibitors on the activity of the enzyme have become a new interesting field of study.

Many specific neuraminidase inhibitors (NIs) have been reported. ${ }^{2,3)}$ These inhibitors, either natural or synthetic, can be divided into two groups: one comprises the analogs and derivatives of neuraminic acid and the other comprises the substances that have no direct connection with the substrate or product of the enzyme. Among the known inhibitors of microbial origin, panosialin ${ }^{4}$ belongs to the latter and siastatin ${ }^{5)}$ to the former.

We have discovered a strong NI activity in the culture fluid of Streptomyces No. 289. ${ }^{6}$ ) Isolation and purification of the NI (NI-289), and chemical and physical properties of the purified NI preparation will be reported.

$\dagger$ Viral-neuraminidase Inhibitors of Microbial Origin. Part III.

\section{MATERIALS AND METHODS}

Microorganism. Streptomyces sp. No. 289 stocked in our laboratory was used.

Culture. The medium used in seed and main culture was composed of $1 \%$ lactose, $0.5 \%$ peptone (Kyokuto), $0.1 \%$ yeast extract (Difco), and $0.05 \% \mathrm{MgSO}_{4} \cdot 7 \mathrm{H}_{2} \mathrm{O}$ in a $0.05 \mathrm{M}$ phosphate buffer, $\mathrm{pH} 6.0(\mathrm{~PB})$. In the seed culture, a loopful of spores and mycelia taken from a stock culture was inoculated into a test tube containing $5 \mathrm{ml}$ of the medium and cultured with shaking at $27^{\circ} \mathrm{C}$ for 2 days. This was then transferred to a shaking flask containing $100 \mathrm{ml}$ of the medium and cultured for 2 days to obtain a seed. The seed was transferred to a 30 liter-jar fermentor containing 15 liters of the medium and cultured at $27^{\circ} \mathrm{C}$ for 3 days with agitation of $400 \mathrm{rpm}$ and aeration of $15 \mathrm{liter} / \mathrm{min}$. Afterwards, the culture broth was filtered through a Toyo-Roshi No. 2 filter paper, and the NI was isolated from this filtrate.

Determination of NI activity. NI activity was expressed in terms of the de-hemagglutination inhibition (deHAI) activity against $2^{6} \mathrm{HA}$ units/ml of influenza $\mathrm{A}_{2} /$ Fukuoka/1/70 virus. Assay method and cultivation of the virus used in the assay was described in the previous paper. ${ }^{6,71}$

DEAE-Sephadex column chromatography. The sample and the eluting solution were run through a column $(2.0 \times 30 \mathrm{~cm})$ of DEAE-Sephadex A-50 previously equilibrated with PB at a flow rate of $10 \mathrm{ml} / \mathrm{hr}$. The effluent was collected in $5 \mathrm{ml}$-fractions.

CM-Sephadex column chromatography. Similarly, 
the sample and the elution solution were run at $10 \mathrm{ml} / \mathrm{hr}$ through a column $(1.6 \times 25 \mathrm{~cm})$, and the effluent was collected in $5 \mathrm{ml}$-fractions.

Sephadex G-200 column chromatography. The sample was charged to a column $(2 \times 100 \mathrm{~cm})$ previously equilibrated with $\mathrm{PB}$ and eluted with the same buffer at a flow rate of $10 \mathrm{ml} / \mathrm{hr}$. The effluent was collected in $5 \mathrm{ml}$ - fractions.

Polyacrylamide gel disc electrophoresis. This was carried out according to H.R. Maurer, ${ }^{8)}$ using $\mathrm{pH} 4.3$ $7.5 \%$ gel system (System No. 8). Electrophoresis was preformed at $2 \mathrm{~mA}$ per tube for $4 \mathrm{hr}$. The developed gel was stained with Coomassie Brilliant Blue R-250 for protein, or was cut into $5 \mathrm{~mm}$-sections and the sugar content of each cut was determined by phenol- $\mathrm{H}_{2} \mathrm{SO}_{4}$ method $^{91}$ after elution with $0.5 \mathrm{ml} \mathrm{PB}$ with shaking for overnight.

Determination of molecular weight. Molecular weight was estimated with an ascending column $(2.5 \times$ $45 \mathrm{~cm}$ ) of Sephadex $\mathrm{G}-200$ at $\mathrm{pH} 6.0$, using some pure substances of known molecular weights as standards.

Light absorbance and specific rotation. UV and IR absorption spectra and specific rotation were measured using a Shimazu Model MPS-50 L spectrophotometer, Model DS-402 G spectrophotometer (Japan Spectroscopic Co.) and Model DIP-S automatic polarimeter (Japan Spectroscopic Co.), respectively.

Elementary analysis. This was conducted by the Elementary Analysis Laboratory of the Institute of Applied Microbiology.

Determination of total sugar and protein. Total sugar content was determined by phenol- $\mathrm{H}_{2} \mathrm{SO}_{4}$ method, ${ }^{9 !}$ and total protein content by Lowry's method. ${ }^{101}$

Color tests for sugars. Uronic acid was detected by Tollens' method ${ }^{11}$ and carbazole- $\mathrm{H}_{2} \mathrm{SO}_{4}$ method, ${ }^{12}$ ) amino sugar by Elson-Morgan's method, ${ }^{13)}$ aldopentose by Bial's method, ${ }^{14}$ aldohexose by cystein- $\mathrm{H}_{2} \mathrm{SO}_{4}$ method, ${ }^{15}$, ketose by carbazole- $\mathrm{H}_{2} \mathrm{SO}_{4}$ method ${ }^{16}$ ) and deoxy-sugar by Kiliani's method. ${ }^{171}$

Quantitative analysis of neutral sugar. Ten milligrams of the sample was dissolved in $10 \mathrm{ml}$ of $2 \mathrm{~N} \mathrm{HCl}$ and vacuum-sealed in a glass tube. After hydrolysis at $100^{\circ} \mathrm{C}$ for $20 \mathrm{hr}$ and expellation of the $\mathrm{HCl}$, the sugar was analyzed by i), a Japan Electron Optics Lab's liquid chromatograph, Model JLC-3BC, ii), thin layer chromatograph with Silica gel $\mathrm{G}^{18}$ impregnated with $5 \% \mathrm{NaH}_{2} \mathrm{PO}_{4}$ (pyridine/ethyl acetate/acetic acid/ $\left.\mathrm{H}_{2} \mathrm{O}=5 / 5 / 1 / 3\right)$ and Abicel SF plates ${ }^{19)}(\mathrm{BuOH} /$ acetone/ $\mathrm{H}_{2} \mathrm{O}=4 / 5 / 1$ ), using a diphenylamine aniline solution as the coloring agent for the sugars, and iii), after converting to TMS-derivatives, by Gas-Liquid chromatograph,
Shimadzu Model GC 4A, attached with a hydrogen flame detector.

Quantitative analysis of amino acids and amino sugars. Five milligrams of the sample was dissolved in $10 \mathrm{ml}$ of $6 \mathrm{~N} \mathrm{HCl}$ and sealed under vacuum into a glass tube. After heating at $110^{\circ} \mathrm{C}$ for $20 \mathrm{hr}$, the solution was evaporated to dryness under reduced pressure to expire the $\mathrm{HCl}$. The residue was dissolved in $5 \mathrm{ml}$ of water and analyzed by an analyzer of Japan Electron Optics Lab's product, Model JLC-5AH.

Determination of $N$-acetylneuraminic acid (NANA). One-half milligram per $\mathrm{ml}$ of the NI was hydrolyzed by $0.1 \mathrm{~N} \mathrm{H}_{2} \mathrm{SO}_{4}$ at $80^{\circ} \mathrm{C}$ for $1 \mathrm{hr}$. The hydrolysate thus obtained was treated according to Warren's method ${ }^{201}$ and the color developed was compared with authentic NANA.

Treatment with proteolytic enzymes. The NI (1mg/ $\mathrm{ml})$ was incubated with various kinds of proteolytic enzymes $(0.2 \mathrm{mg} / \mathrm{ml})$ at $37^{\circ} \mathrm{C}$ for $1 \mathrm{hr}$. Afterwards, the reaction mixtures were boiled for $10 \mathrm{~min}$ to inactivate the enzymes before the deHAI assay.

Periodate decomposition. ${ }^{21)}$ One-half milligram per $\mathrm{ml}$ of the NI was incubated with $0.05 \mathrm{M} \mathrm{NaIO}_{4}$ at $5^{\circ} \mathrm{C}$ for $72 \mathrm{hr}$. Afterwards, the $\mathrm{NaIO}_{4}$ was decomposed by ethylene glycol and the mixture was dialyzed against distilled water.

Chemicals. DEAE-Sephadex A-50, CM-Sephadex C-50 and Sephadex G-200 were the products of Pharmacia, Upsala. All the proteolytic enzymes were purchased from Sigma Chemical Company with one exception that trypsin is a product of Difco Laboratories, Michigan, U.S.A. The remaining chemicals were in the purest grade.

\section{RESULTS}

\section{Isolation and purification of the NI-289}

i) Ethanol precipitation. Culture filtrate was precipitated by ethanol up to $55 \%$ saturation for 2 times. The precipitate thus obtained was fractionated by precipitation at $0 \sim 30 \%$, $30 \sim 50 \%$ and $50 \sim 70 \%$ of ethanol; NI activity per sugar unit was predominately gathered in the $30 \sim 50$ fraction. This fraction was collected, heated at $100^{\circ} \mathrm{C}$ for $10 \mathrm{~min}$. The inactive precipitate occurred was removed by filtration and the filtrate was subjected to ionexchange chromatography.

ii) DEAE-Sephadex chromatography. As shown in Fig. 1, NI activity was divided into 


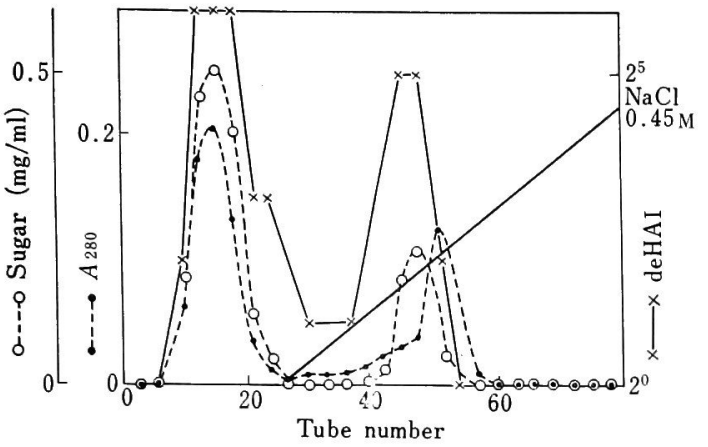

FIG. 1. Separation of the NI-289 by DEAE-Sephadex A-50 Chromatography.

$\mathrm{PB}$ was used as the basal eluting solution.

two parts, one in the non-adsorpted fraction and the other in the weakly-adsorpted fraction. The former fraction was used in the following experiments, as it occupied two-thirds of the total activity.

iii) CM-Sephadex chromatography. Under the experimental condition, the NI activity was not adsorbed by CM-Sephadex and eluted out in the $0 \mathrm{M}-\mathrm{NaCl}$ fraction (Fig. 2).

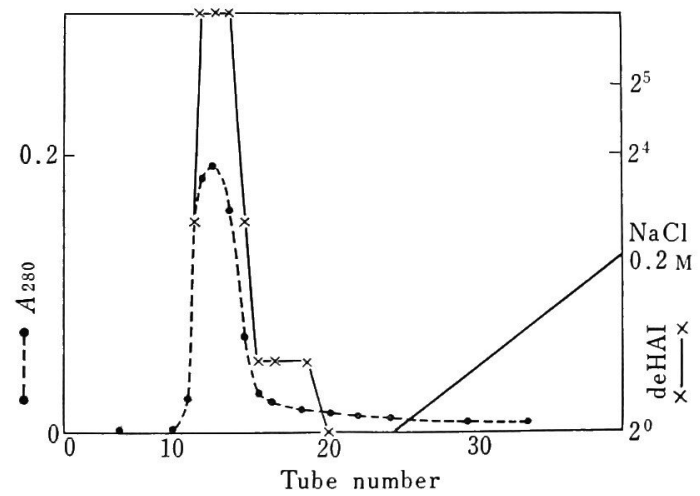

FIG. 2. CM-Sephadex C-50 Chromatography of the NI-289.

PB was used as the basal eluting solution.

iv) Sephadex G-200 chromatography. When the NI preparation obtained in the above section was applied to a Sephadex G-200 column, a symmetrical active peak appeared after void volume, showing that the NI had been highly purified. This peak coincided with $A_{280}$ and sugar content (Fig. 3).

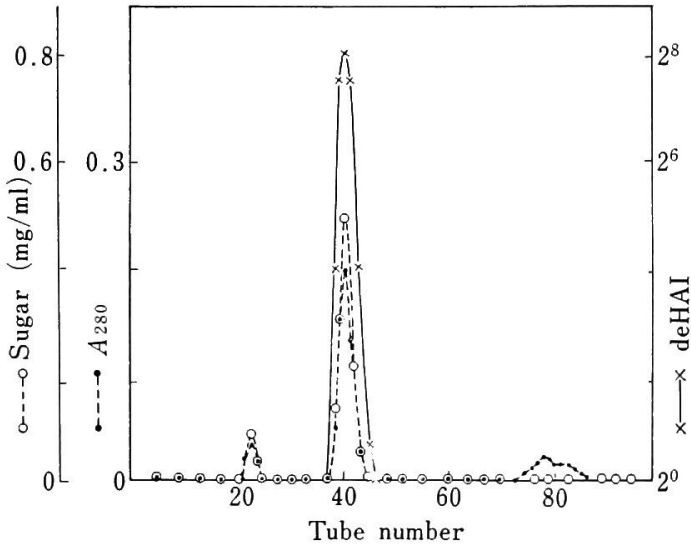

FIG. 3. Gel Filtration of the NI-289 by Sephadex G-200.

v) Summary of purification. Table I gives a summary of the purification. A great loss of the activity in the ethanolic precipitation step was due to removal of a large amount of the material insolubilized by the ethanol. NI activity per protein unit and per sugar unit reached steady values at the DEAE Sephadex step. Finally, about $500 \mathrm{mg}$ of the NI was obtained as white powder. The yield of activity was $11 \%$.

\section{Criterion of purity}

Purity of the NI preparation obtained above was checked by polyacrylamide gel disc electrophoresis. As shown in Fig. 4, a single band moving towards cathode at $\mathrm{pH} 4.5$ was detected by protein staining and determination
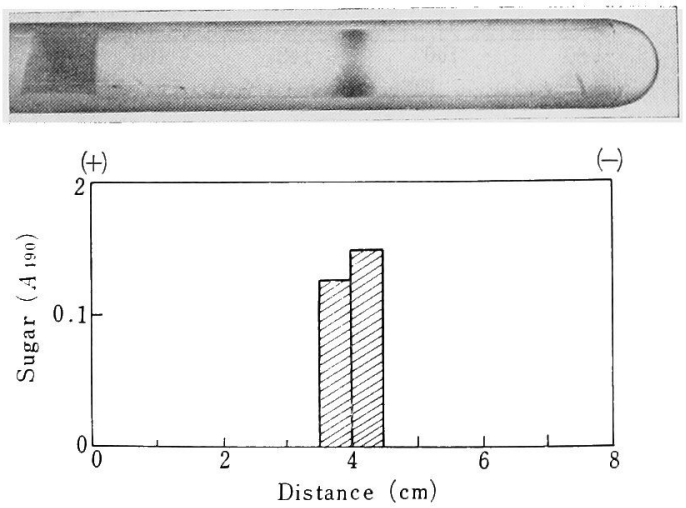

FIG. 4. Disc Electrophoresis of the NI-289 on Polyacrylamide Gel. 
Table I. Summary of the Purification of The NI-289

\begin{tabular}{|c|c|c|c|c|c|c|c|}
\hline Procedures & $\begin{array}{l}\text { Volume } \\
\text { (1) }\end{array}$ & $\underset{\text { Sugar }}{\text { (mg) }}$ & $\begin{array}{c}\text { B } \\
\text { Protein } \\
\text { (mg) }\end{array}$ & $\begin{array}{c}\text { C } \\
\text { deHAI } \\
\text { Activity }\end{array}$ & $\mathrm{C} / \mathrm{A}$ & $\mathbf{C} / \mathbf{B}$ & $\mathbf{A} / \mathbf{B}$ \\
\hline \multicolumn{8}{|l|}{ Culture } \\
\hline $\begin{array}{l}\text { filtrate } \\
\text { EtOH ppt, }\end{array}$ & 25 & 30,000 & 25,000 & 200,000 & 6.7 & 8.0 & 1.2 \\
\hline $\begin{array}{l}\text { 2nd }(0 \sim 55 \%) \\
\text { EtOH ppt }\end{array}$ & 1 & 840 & 280 & 102,400 & 121.7 & 565.7 & 3.0 \\
\hline $\begin{array}{l}(30 \sim 50 \%) \\
\text { Heat }\end{array}$ & 0.6 & 660 & 130 & 38,400 & 58.2 & 295.7 & 5.1 \\
\hline $\begin{array}{l}\text { treatment } \\
\text { DEAE- }\end{array}$ & 0.6 & 630 & 90 & 38,400 & 61.0 & 426.7 & 7.0 \\
\hline $\begin{array}{l}\text { Sephadex } \\
\text { Sephadex }\end{array}$ & 0.7 & 515 & 71 & 25,600 & 49.7 & 360.6 & 7.3 \\
\hline G-200 & 0.7 & 440 & 59 & 22,300 & 50.8 & 376.5 & 7.4 \\
\hline
\end{tabular}

of sugar content.

III. Physical properties of the NI-289

i) Molecular weight. The molecular weight of the NI was about 100,000 as determined by a Sephadex G-200 gel filtration (Fig. 5).

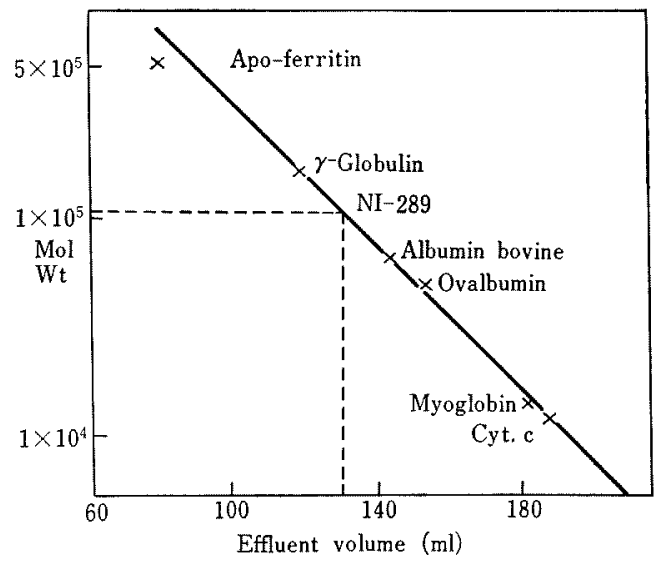

FIG. 5. Estimation of Molecular Weight of the NI289 by Sephadex G-200 Chromatography.

ii) Light absorbance. $\mathrm{UV}_{\max }$ : No peak of absorption, but only a shoulder around $275 \mathrm{~nm}$ (Fig. 6): IR $\mathrm{I}_{\max }: 3360,2920,1640$, $1540,1040 \mathrm{~cm}^{-1}$ (Fig. 7)

iii) Specific rotation. $\quad \alpha_{\mathrm{D}}^{20}(c=0.5,0.05 \mathrm{M}$ PB): +86

iv) Thermal stability. As shown in Table

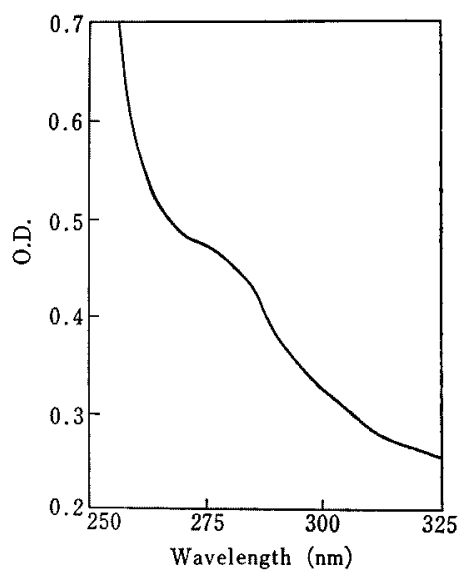

FIG. 6. UV Spectrum of the NI-289 (0.1\% in PB).

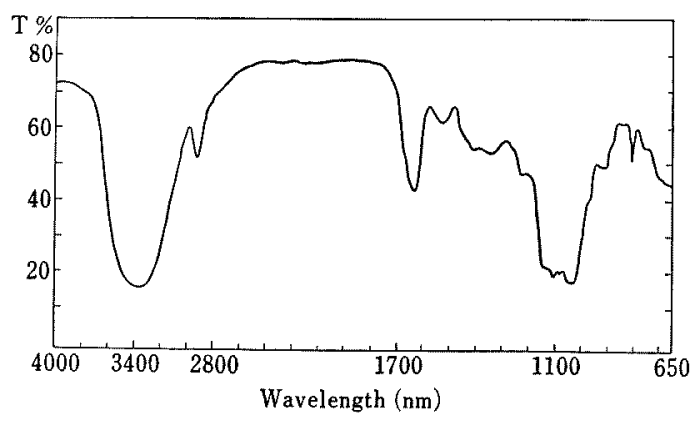

FIG. 7. IR Spectrum of the NI-289 (KBr tablet).

II, the NI was stable to heating at $100^{\circ} \mathrm{C}$ for $10 \mathrm{~min}$. 
Table II. Thermal Stability of the NI-289

The NI was dissolved in $0.05 \mathrm{M} \mathrm{PB} \mathrm{(pH} \mathrm{6.0)} \mathrm{and}$ heated for $10 \mathrm{~min}$ in each experiment.

\begin{tabular}{cc}
\hline Temperature & $\begin{array}{c}\text { deHAI Activity } \\
\text { (Units/25 } \mu \text { g NI) }\end{array}$ \\
\hline $60^{\circ} \mathrm{C}$ & $2^{7}$ \\
70 & $2^{7}$ \\
80 & $2^{7}$ \\
90 & $2^{7}$ \\
100 & $2^{7}$ \\
Control & $2^{7}$ \\
\hline
\end{tabular}

IV. Chemical properties of the NI

i) Elementary analysis. A result of elementary analysis of the NI was as follow:

$\begin{array}{llllll}\mathrm{C} & \mathrm{H} & \mathrm{N} & \mathrm{O} & \mathrm{S} \mathrm{P}\end{array}$

$\begin{array}{lllll}37.33 & 6.12 & 1.29 & 55.2600 & 0\end{array} \%$

$\begin{array}{llll}34.56 & 67.44 & 1 & 37.50 \quad \text { (atomic }\end{array}$

ratios based on $\mathrm{N}$ )

Sulfur and phosphorus were absent from the NI.

ii) Total sugar and protein contents. The total sugar and protein contents of the NI preparation were $88 \%$ and $12 \%$ when estimated by phenol- $\mathrm{H}_{2} \mathrm{SO}_{4}$ method and Lowry's method, respectively.

iii) Sugar composition. The result of color tests for sugars is shown in Table III; the NI was positive in Elson-Morgan, cystein$\mathrm{H}_{2} \mathrm{SO}_{4}$ and carbazole- $\mathrm{H}_{2} \mathrm{SO}_{4}$ reactions. Only the two monosaccharides, glucose and mannose, were detected by thin-layer chromatography (Fig. 8) and gas liquid chromatography (Fig. 9). However, two additional minor

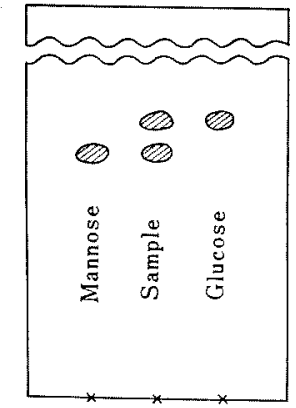

Silica gel, $5 \% \mathrm{NaH}_{2} \mathrm{PO}_{4}$ (pyridine/EtOAc acetic acid $/ \mathrm{H}_{2} \mathrm{O}$ $=5: 5: 1: 3$ )

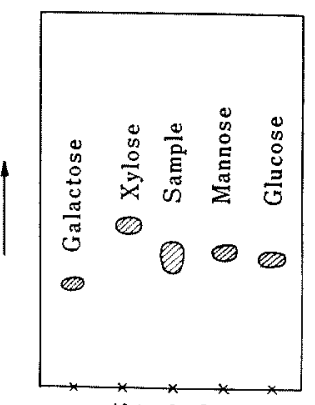

Abicel SF

(BuOH/pyridine/

$\mathrm{H}_{2} \mathrm{O}=6: 4: 3$ )
FIG. 8. Thin-layer Chromatography of the Hydrolysate of the NI-289.

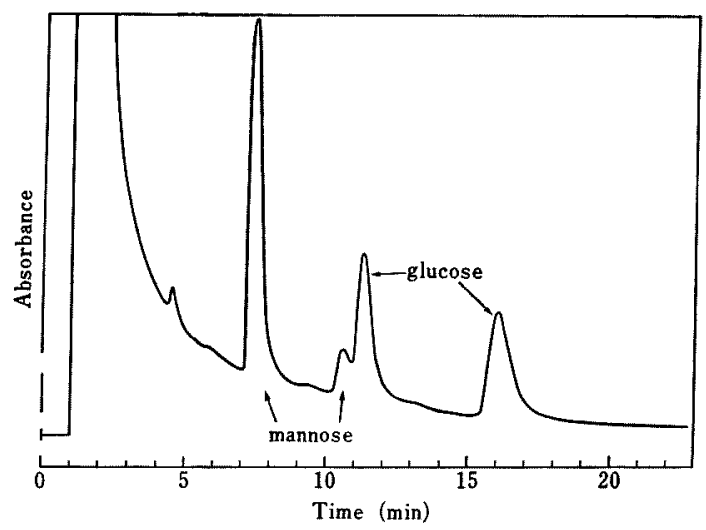

FIG. 9. Gas-liquid Chromatography of the TMShydrolysate of the NI-289.

Column, $0.75 \%$ OV-17 column, $3 \mathrm{~m}$; temperature, $170^{\circ} \mathrm{C} ; \mathrm{N}_{2}$ flow, $32 \mathrm{ml} / \mathrm{min}$.

peaks appeared between mannose and glucose on the liquid chromatography (Fig. 10).

iv) Amino acid and amino sugar composi-

Table III. Color Tests for the Sugar Residues of the NI-289

\begin{tabular}{llll}
\hline Sugars & Reactions & Standard colors & \multicolumn{1}{c}{ Colors developed } \\
\hline Uronic acid & Tollen's & Blue-violet & $\begin{array}{l}\text { Light brown followed by deep } \\
\text { orange brown }\end{array}$ \\
& & & Gray \\
Uronic acid & Carbazol- $\mathrm{H}_{2} \mathrm{SO}_{4}$ & Red & Pink \\
Amino sugar & Elson-Morgan's & Pink & Light yellow brown \\
Aldo-pentose & Bial's & Blue & Golden yellow \\
Aldo-hexose & Cystein- $\mathrm{H}_{2} \mathrm{SO}_{4}$ & Golden yellow & Red-violet \\
Ketose & Carbazol- $\mathrm{H}_{2} \mathrm{SO}_{4}$ & Red, red-violet & Yellowish brown ring \\
Deoxy-sugar & Kiliani's & Blue ring &
\end{tabular}




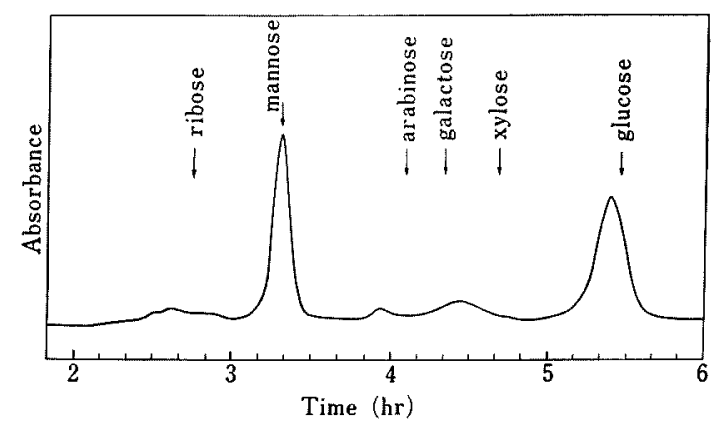

FIG. 10. Liquid Chromatography of the Hydrolysate of the NI-289.

Column, JEOL LC-R-3 resin column, $0.8 \times 15 \mathrm{~cm}$; color development, orcinol $-\mathrm{H}_{2} \mathrm{SO}_{4}$ reaction at $90^{\circ} \mathrm{C}$ for $10 \mathrm{~min}, A_{423}$ was scanned; Flow rate of borate buffer, $0.52 \mathrm{ml} / \mathrm{min}$.

tion. Table IV shows a result obtained by an amino acid analyzer. Neutral amino acids were the main components. S-Containing

Table IV. Amino Acid Composition of THE NI-289

\begin{tabular}{lrlr}
\hline Lysine & $2.6 \mathrm{~mol} \%$ & Alanine & 12.6 \\
Arginine & 1.9 & Valine & 9.2 \\
Aspartic acid & 7.3 & Isoleucine & 5.0 \\
Threonine & 5.7 & Leucine & 7.5 \\
Serine & 3.4 & Tyrosine & 3.5 \\
Glutamic acid & 6.9 & Phenylalanine & 4.4 \\
Proline & 3.0 & & \\
Glycine & 21.8 & Glucosamine & 4.9 \\
& & & $\frac{100.0}{}$ \\
\hline
\end{tabular}

amino acids could not be detected; this coincided with the result of the elementary analysis. As to amino sugars, only a small amount of glucosamine was detected. No NANA could be found in an acid hydrolysate of the NI. When the mild-acid hydrolysate was treated by Warren's method for NANA analysis, the color developed showed peaks of absorption at $525 \mathrm{~nm}$ and $450 \mathrm{~nm}$, which are common to monosaccharide, other than at $549 \mathrm{~nm}$ which is specific for NANA.

v) Effects of proteolytic enzymes on the activity. As shown in Table $\mathrm{V}$, the inhibitory activity of the NI was not destroyed by the enzymes at all.
Table V. Effects of Proteolytic Treatment ON THE NI-289

\begin{tabular}{lcc}
\hline \multicolumn{1}{c}{ Enzymes } & $\begin{array}{c}\text { Reaction } \\
\text { pH }\end{array}$ & $\begin{array}{c}\text { deHAI } \\
\text { Activity (Units } \\
/ 25 \mu \mathrm{g} \mathrm{NI}\end{array}$ \\
\hline Trypsin, pancreas, 1:250 & 7.0 & $2^{7}$ \\
Pepsin, 1: 60,000 & 3.0 & $2^{7}$ \\
Protease, Strep. griseus & 6.0 & $2^{7}$ \\
Papain, 2X crystld. & 6.0 & $2^{7}$ \\
$\begin{array}{l}\alpha \text {-Chymotrypsin, bovine } \\
\text { pancreas, } 3 \times \text { crystld. }\end{array}$ & 6.0 & \\
Control & & $2^{7}$ \\
\hline
\end{tabular}

vi) Effects of periodate treatment on the activity. The deHAI and NI activities of the NI were examined after periodate treatment. Table VI indicates that both activities were lowered by this treatment.

\section{Table VI. Effect of Periodate Treatment} ON THE ACTIVITY OF THE NI-289

NI-289 was treated with $\mathrm{NaIO}_{4}$ as described in Materials AND Methods. The residual activity was determined by measuring effects on neuraminidase activity and deHA. The neuraminidase reaction mixture contained the Pennsylvania strain of Newcastle disease virus ( $2^{3} \mathrm{HA}$ units $/ \mathrm{ml}$ ) and $500 \mu \mathrm{g} / \mathrm{ml}$ neuramin lactose in PB with or without NI-289 $(125 \mu \mathrm{g} / \mathrm{ml})$. Enzyme activity was expressed as $A_{650}$ of the liberated neuraminic acid which was determined by the thiobarbituric acid method.

\begin{tabular}{|c|c|c|c|}
\hline & \multicolumn{2}{|c|}{$\begin{array}{l}\text { Neuraminidase- } \\
\text { inhibition activity }\end{array}$} & \multirow{2}{*}{$\begin{array}{c}\text { deHAI } \\
\text { activity } \\
\text { (Units } / 25 \mu \mathrm{g} \\
\mathrm{NI} \text { ) }\end{array}$} \\
\hline & $A_{550}$ & $\%$ inhibition & \\
\hline Control & 0.48 & 一 & 0 \\
\hline NI-289 & 0.16 & 66 & $2^{6}$ \\
\hline \multicolumn{4}{|l|}{ NI-289 } \\
\hline (Treated) & 0.24 & 50 & $2^{4}$ \\
\hline
\end{tabular}

\section{DISCUSSION}

Inhibitors specific to neuraminidase can be arbitarily classified ${ }^{2)}$ as analogs and derivatives of neuraminic acid $^{10,22 \sim 26)}$ or as substances with no direct connection to the substrate or product of the enzyme. ${ }^{27,28,31}$ ) The present NI, NI-289, can be classified in the latter group, because it is a glycoprotein composed mainly of neutral sugars and does not contain NANA as determined by Warren's thiobarbituric acid procedure after mild acid 
hydrolysis. This procedure is by far the most sensitive method for the analysis of free sialic acids. ${ }^{29)}$ Hydrolysis of glycoprotein with $0.1 \mathrm{~N}$ $\mathrm{H}_{2} \mathrm{SO}_{4}$ at $80^{\circ} \mathrm{C}$ for $1 \mathrm{hr}$ completely liberates the sialic acids contained in it. $^{20)}$ It was pointed out that bovine $\mathrm{N}$, O-diacetylneuraminic acid gave no color at all in the thiobarbituric acid procedure and that preliminary $\mathrm{O}$-deacetylation by treatment with alkali at room temperature or by mild acid hydrolysis resulted in complete reactivity in the same procedure. ${ }^{30)}$ In addition, this NI does not contain amino sugars but a small amount of glucosamine which has not been reported to be inhibitory to neuraminidase and its $\mathrm{N}$-acetyl derivative did not interfere with viral deHAI as shown in the previous paper. ${ }^{6}$ Furthermore, the inhibition of neuraminidase by this NI is not competitive against neuraminic acid-containing substrates (unpublished). Thus, this NI resembles to panosialin, ${ }^{4)}$ a microbial NI, which has no structural connection to neuraminic acid.

However, the NIs, including panosialin, in the latter group are generally anionic. The NI-289 is a neutral substance because it was not adsorbed on either DEAE Sephadex or CM Sephadex. It does not contain sulphur or phosphorus, either.

The NI-289 was shown to have a molecular weight of about 100,000 by Sephadex G200 gel filtration. Such a high molecular weight NI has never been reported in microorganisms. Considering that all the known high molecular weight substances without relationship in structure with neuraminic acid are polyanionic ones, e.g., DNA, RNA, heparin and dextran sulfate, ${ }^{31)}$ this NI is very unique and novel.

The present NI is considered as a peptidoglycan. The preparation analyzed for sugar and protein contents was chromatographically and electrophoretically pure, and the repeated preparation of this NI always gave the same sugar-protein ratio. However, its inhibitory activity is considered to reside in the sugar portion, because the activity was insensitive to treatment with proteolytic enzymes and heat but sensitive to periodate treatment.

Acknowledgement. We are expressing our hearty thankfulness to Dr. T. Ikegawa and Dr. K. Ikeda of the National Cancer Center Research Institute, Tokyo, for advices in chemical analysis of the neuraminidase inhibitor, and to Dr. Y. Takeuchi, Chief Researcher of the National Institute of Health, Tokyo, for the influenza $\mathrm{A}_{2} /$ Fukuoka/1/70 virus.

\section{REFERENCES}

1) A. Gottschalk, "The Enzymes," 2nd Edition, Vol.4 Academic Press, N.Y., 1960, p. 461.

2) R. Drzeniek, Current Topics in Microbiology and Immunology, 59, Springer-Verlag, Berlin, 1972, p. 35 .

3) K. Yoshida, T. Okuyama and M. Nomoto, Kagaku to Seibutsu, 11, 242 (1973).

4) T. Aoyagi, M. Yagisawa, M. Kumagai, M. Harada, Y. Okami, T. Takeuchi and H. Umezawa J. Antibiotics, 24, 860 (1971).

5) T. Komiyama, T. Aoyagi, H. Morishima, T. Takeuchi and H. Umezawa, Seikagaku, 45, 548 (1973).

6) W. L. Lin, K. Oishi and K. Aida, Agr. Biol. Chem., 39, 759 (1975).

7) W. L. Lin, K. Oishi and K. Aida, Agr. Biol. Chem., 39, 917 (1975).

8) H. R. Maurer, "Disc Electrophoresis and Related Techniques of Polyacrylamide Gel Electrophoresis," Walter de Grayter, N.Y., 1971, p. 46.

9) M. Dubois, K. A. Gilles, J. K. Hamilton, P. A. Rebers and F. Smith, Nature, 168, 107 (1951).

10) O. H. Lowry, N. J. Rosebrough, A. L. Farr and R. J. Randall, J. Biol. Chem., 193, 265 (1951).

11) B. Tollens, Ber., 41, 1788 (1908).

12) Z. Dische, J. Biol. Chem., 167, 189 (1947).

13) L. A. Elson and W. T. J. Morgan, Biochem. J., 27, 1824 (1933).

14) J. B. Summer, J. Am. Chem. Soc., 45, 2378 (1923).

15) Z. Dische, L. B. Shettles and Osnos, Arch. Biochem., 22, 189 (1949).

16) Z. Dische and E. Borenfreund, I. Biol. Chem., 192, 589 (1951).

17) H. Kiliani, Arch. Pharm., 251, 867 (1913).

18) Yu.S. Ovodof, V.E. Vaskovsky, E.V. Extushenko, R.G. Ovodava and T.F. Solovera, J. Chromatog., 26, 111 (1967).

19) M. L. Wolform, D. L. Patin and M. de Lederkremer, J. Chromatog., 17, 488 (1965).

20) L. Warren, J. Biol. Chem., 234, 1971 (1959).

21) R. G. Spiro, ibid., 239, 567 (1964).

22) J.N. Walop, Th.A.C. Boschman and J. Jacobs, Biochim. Biophys. Acta, 44, 185 (1960).

23) R. Drzeniek, Z. Med. Mikrobiol. Immunol., 155, 315 (1970).

24) R. Drzeniek, ibid., 156, 1 (1970). 
25) P. Meindl, G. Bodo, J. Lindner and P. Palese, $Z$. Naturforsch., 26b, 792 (1971).

26) A.Ya. Khrlin, I.M. Privalova, L.Ya. Zakstelskava, E.V. Molibog and N.A. Evstigneeva, FEBS Letters 8, 17 (1970).

27) J. D. Edmond, R. G. Johnston, D. Kidd, H. J. Rylance and R.G. Sommerville, Brit.J. Pharmacol.
Chemother, 27, 415 (1966).

28) S. Årerfeldt, J. Med. Chem., 14, 596 (1971).

29) G.W. Jourdian, L. Dean and S. Roseman, J. Biol. Chem., 246, 430 (1971).

30) D. Aminoff, Biochem. J., 81, 384 (1961).

31) R. Drzeniek, Nature, 211, 1205 (1966). 